\title{
Some aspects of economic geographic views at the geological makeup: the case northeastern Montenegro
}

\author{
Goran Rajović $^{1, *}$, Jelisavka Bulatović ${ }^{2, * *}$ \\ ${ }^{1}$ Street Vojvode Stepe 252, Belgrade, Serbia \\ Phone: 0038161/19-24-850 \\ ${ }^{2}$ College of Textile Design, Technology and Management, \\ Street Starine Novaka 20, Belgrade, Serbia \\ Phone: 003861/ 3082651
}

*,**E-mail address: dkgoran.rajovic@gmail.com , jelisavka.bulatovic@gmail.com

\begin{abstract}
This paper discusses some aspects of the economic and geographic look at the geological structure of northeastern Montenegro. The geological structure of part all three groups of rocks metamorphic, igneous and sedimentary. When viewing certain kinds of rock and emphasized their economic importance. The considered area has excellent possibilities for development of mining, particularly as Berane basin contains significant reserves of brown coal and lignite (176.231.197 tons). Since metallic materials have be discovered bearing the following metals: lead, zinc, copper, iron and pyrite. A deposit of non-metallic building materials: gravel, sand and decorative stone. Northeastern Montenegro has exceptional opportunities for the development of industry, whose focus should be about $\mathrm{n}$ Berane coal production in the basin, which would cause intense regrouping and integration of industrial enterprises, which would undoubtedly affect the entire economic life of the considered geographic space.
\end{abstract}

Keywords: Northeastern Montenegro; geological structure; metamorphic rocks; igneous rocks; sedimentary rocks; agriculture; construction; industry; economic geography

\section{INTRODUCTION}

Question of geological structure and its economic importance can be set in different ways. At this point in history, and in modern development, there are different views and interpretations. This has certainly created a rich scientific base is necessary for the determination of further research. "Dealing with the geology, numerous authors have also analyzed and its economic importance. They have this complex natural economic process in the economic and geographical theory and practice, observed in many aspects, either directly or in the analysis of the overall socio-economic trends" [1]. Thus, the geological structure of this part of north-eastern part of Montenegro, all three groups of rocks: metamorphic, igneous and sedimentary. When viewing a particular type of rock it is noted that they can be used in commercial purposes. Sedimentary rocks occupy a dominant place in the geological structure 
of the north-eastern Montenegro, and we know that in today's technology there is a sedimentary rock that has not found its application, while some of them are the essential components without which one can not imagine modern human activity. Economic aspects of the evaluation indicate the possibilities of use of agricultural, construction and industrial purposes [2-4]. In this paper we will not deal with the tourist aspects of the evaluation, since it is the topic of the study was the subject of many authors. Among them this time emphasize this: [5-9].

\section{RESEARCH METHODOLOGY}

The methodology primarily based on an analysis of existing literature about the geological structure of the northeastern Montenegro. From the existing literature, we used both domestic and those published in the international literature. Were study and written sources on the internet? The scientific explanation of terms, we applied two methods are used: analytic and synthetic. Analytical methods considered some of the dimensions of the research topic, and a synthetic whole, the interconnections between the case and suggested measures that derive there from.

Starting from these, explanations and we based our theoretical premises from which we started in defining the objectives of the study and the importance of the geological structure of northeastern Montenegro. With the goal of defining the notion that we have accepted are basic geological research to date have mostly been oriented to larger spatial units (former Yugoslavia, Montenegro) and less on specific areas or regions. This also applies to the considered geographical space, which in this sense, to our knowledge, has not been analyze with complex geological review. The interpreter for the basic geological map $[10,11]$ unless otherwise noted, gives basic characteristics of the geological structure of the considered Geospatial.

\section{ANALYSIS AND DISCUSSION}

\section{1. Metamorphic rocks}

Metamorphic rocks in the geological structure of the observed proportion of geo occupy large areas. The presented Paleozoic schist's, limestones, sandstones, dolomite limestones and conglomerates [12]. It is manifested in the village of Sutjeska and the move from Balja to Trepča, around Ulotina, Murina, Brezojevice, Velike, Čakora, Rađevića, Babinog fields, Đuričke River, Prnjavora, Lazija, Kačanika, Upper Rženice, Great and Small rocks, Duba, Lower and Upper Vrbice, Radmuževića, Jelenaka, Turije, Drenove head, Rudog hills, Trešnjevika, Sovala it is the valley Kraštice, Gradišnjice, Bastaške River, Brzave and Ševarinske River the limestone, shale, sands and conglomerates. In the village of Murina and Luge Paleozoic broke through considerable mass of green and decomposed eruptive. Patchy Paleozoic shale makes material Cmiljevica and right Jošaničke, Radmanske i Vrbičke River. Dolomite limestone occurs in the original part of the Bistrica River (tributary of River Plain) Turjaka, Šiškog lake, Bjelasica and Steep drop [13].

Among are metamorphic smallest number of economically useful rocks, especially if they are highly schistose texture. Yet talking shale could find its place in the cosmetics, chemical industry, rubber industry, paper, pesticides. While are limestone was very broad, both in construction and in the chemical industry. Until then, do not file processing 
conglomerates and their use is very limited, but not sandstones that could have been using in the construction of a technical and architectural stone (http://www.pmf.ni.ac.rs) [14].

Permian sediments have been expos to a much smaller space than other Paleozoic sediments. They are made with laminated shale, clay shale's, Phillies (Previjansko hill, Turjak), limestone and dolomite limestone (source of the Bistrica River (tributary of River Plain), Turjak, Šiško lake, Bjelasica and the Steep decline)). Permian age sediments thickness is about $300 \mathrm{~m}$. Perm -Trier formations were found in the eastern part of the studied GeoScape, represented by conglomerates in the Visova, Starca and Pasjeg top.

From the point of view of agriculture impermeable shale Paleozoic (Phyllis, argil logiest) are subject to decay and washing away, and on steep surfaces covered by thin soil of, Hum-silicate soils (rankers), limestone and dolomite humus (Kalkomelanosol) or districtbrown soil (district camisole). Rankers belong to the land with poor agricultural production capabilities. These are mostly shallow and undeveloped land genetically. Only deep eutric rankers, and in good weather conditions are considered GeoScape, a better woodland habitat.

Kalkomelanosol or mountainous black soil is also shallow soil and low water retention. Because plants grown on black soils depend on are amount and distribution of precipitation. Mostly it forested land. Districts camisole usually spread in the observed area in areas where the annual rainfall is above $700 \mathrm{~mm}$. Natural vegetation of the area consists of forests. However, reclaimed land under the land can been used as meadows and pastures, but also as an area for growing potatoes, oats, barley, and rye. Podzol natural vegetation in this part of northeastern Montenegro consists of forests with spruce, white pine and moss in the ground floor, but can also be found under beech and birch trees and vegetation as secondary usually occur bilberry and heather. These geological formations and these types of land cover significant areas in the western, southeastern, northern and northeastern part of the studied area. On the flat surfaces of fragments of soil cover thickness is much greater. "Argil logiest and Phillies are low-grade metamorphic rocks of fine grain, dark gray to black in color and occur in thin plates, which can be easily split up. From the standpoint of construction are used as roofing slates because they have little porosity and resistant to weathering" (http://www.pmf.ni.ac.rs) [14].

Cretaceous formations are represented on the left Grnčara, left and right Vrulje and right Ljuče through the limestone breccias, breccias limestone's, dolomites and flinch. During are construction of roads in the flinch greatest danger - a possibility of unstable slopes and deep ravines and frequent. During underground work, problems arise with crushed clay and yeast compo - nets flinch. Examples of very heavy construction and frequent landslides especially on the roads have Plav-Gusinje basin.

Terrain composed of serpentines because scaling is unsuitable for surface and underground operations (subject to erosion). For example, the terrain composed of shale with favorable characteristics for core and underground operations. If however schistose texture, their stability decreased rapidly. Slate lower level have good characteristics for making ground if they are fresh, making enclosures and cuts more difficult, and as building materials and these rocks are not used. Marbles have all the good properties required for construction, both surface and underground facilities. Of course, as with lime, certification decreases the stability of such courts. 


\section{2. Igneous rocks}

Igneous rocks in the geological structure of the northeastern part of Montenegro, participate in a much smaller scale. They occur in Bjelasica (near the Small and Great Šiškog Lake, Pešića Lake on the left side of the river Jelovice), Visitor, Greben, Lipovica and Zeletin. Well demonstrate on the right side of Lima at Sjekirice. Approximately Berane (Beran Village and Jerincity), these rocks occur in the form of tubular mass, which may represent a volcanic channels, erosion stripped. According to the survey of mineral resources in the release of the Federal Bureau Geo (1982), igneous rocks, especially spilt and dibasic, often occur in the dibasic - Chart formation, so that their offspring is very small, so it is usually impossible to eat on the map. From surface igneous rocks are quartz largest extend keratophyre (Bjelasica), and depth of granite and grandiosity (part Bogićevica). "The colors are gray or red, depending on the mineral composition and pigment, granular structure (grained varieties have better tech $\neg$ nicely characteristics), and the most massive textures. Good polish and they is quite resistant to aggressive atmospheric influences" (http://www.beranetownnet) [15]. Of the neutral surface rocks are represented by andesitic and keratophyre (Visitor, Greben, Sjekirica, Lipovica). Yet they "have no significance as the plutonic rocks of variable quantity and size phenomenon of crystal, as well as by the presence of glass in the ground mass. They have been using mainly as crushed stone, largely as aggregate in road construction or in the form of cubes and curbs. These rocks are polymetallic mines $\neg$ holders of mineral resources $(\mathrm{Pb}, \mathrm{Zn}$, and $\mathrm{Cu}) "$ [16].

Dibasic and serpentines occur in Mokra Mountain, seniti the Jankovoj head, and the Fat splits Kaludarska hill near the river, Beran Village and Dapsića. Spilt are fine-grained, often mandolin rocks, green to dark green in color and macroscopic be difficult to distinguish from the dibasic. A disadvantage is that it occurs in small masses and can been used in road construction. "Dibasic are black, but they are structured Enlarged strength of rocks which significantly increased. A disadvantage is that it occurs mainly in small masses and is have used as the highest quality crushed aggregate wear layer in road construction and are development of a specialty concrete. In addition dibasic are the main raw material for producing and mineral wool. Serpentines pleasant colors have used as a good dimension stone [16]. While "seniti may be applied for indoor and outdoor decoration, applied to the construction of piers, small stone bridges, tunnel portals and lining, as well as the foundation for development. Fresh seniti is suitable for use in embankment dams and their coating; during construction roads, and used for the construction of retaining walls, embankments, why on railway lines and roads of a lower order, curbs and sidewalks" (http://www.rgf.ac.rs) [14]. Terrains made with fresh intrusive rocks have very favorable characteristics for the construction of almost all objects; they can have be successfully done stable tunnels and other underground structures larger. If however rocks are very tectonically have fractured or weathered, their quality as a basis similar to are unrelated sedimentary rocks. Extrusive igneous rocks may also be a good base for foundation or construction of buildings in them.

These rocks are however, often around mining hanged allowing them to significantly the technical characteristics, decreasing their capacity - from the virtually unlimited, with fresh, to very small, with loose and broken volcanic rock (http://www.pmf.ni.ac.rs) [14].

From the point of view of agriculture, land on steep slopes (litho sol and rankers) that the surface igneous rocks have been exposing to erosion and acidification and mostly shallow soil with particle skeleton. So litho sol characterized by extreme permeability of water, which is to say that they are extremely environmentally friendly dry habitats, but this land is important for the protection of nature (bonding gravel area). 


\section{3. Sedimentary rocks}

Sedimentary rocks occupy a dominant place in the geological structure of the studied area (constructed from layers of Triassic, Jurassic, Tertiary, Quaternary and Holocene). It is important notice the sedimentary rock in today's technology found their use, without which cannot be imagined modern human activity. Lower Triassic strata have manifested in the village Mašte, Veliđe, Godočelje, Đulićima, Oblo Brdo, hamlet Luke, Jodole, the left Veličke and right Murinske, Šekularske, Dapsićke River, edge Bora and Prokletija, on Predolskoj hill, village Vrbnice and Azanje, Šekularu, Štitu and on both sides Kutske River (Rajović, 2005). Consist of marl shale, but it has been concluding that have distinct facial features. Lower Triassic is having represented in clay (with both sides in the Village of Lima Marsenic River) sandy shale and gray limestone (along the right side of the River Vrulje, southeast of Gusinja). The clay shale is split into shells and sticks and lays them over limestone (Bešić, 1980). "Charts usually appears as cracked, a weak base and the environment for the construction, the construction can only be applied for the preparation of the embankment, but because of the hardness of hard compacted; increased presence of grains or pieces of charts in aggregate for concrete is harmful, because it easily enters the chemical reaction with the cement"(http://www.rgf.ac.rs) [17].

From the point of view of agriculture for the Lower Triassic bound soil types (rigosol, rendzina, podzol, brunipodzol), suitable for agricultural production (land intensive orchards, lawns, forest trees - beech, fir, spruce, pine). Middle Triassic strata have developed in two faces: limestone and dibasic formation. Triassic limestone a face is has mixed with layers of dibasic-chart formation. The best-studied section of the middle-classes Trier is in a steep valley called Marquis. In the lower part have represented by dark clay shale's, and through them lies the sandy marl, and then clean limestone with layers of the cornea. Are limestone's pass into dark reddish limestone. The hill Jejevica represented mottled light gray limestone reddish. Rasojevića head hill in the village of Šekular, south of Berane, built from the Triassic formation, mainly limestone, which lie over layers of rich charts, schist's, porphyries and dibasic. Over Rasojević head lying limestone plain Triassic limestone, which undoubtedly belong to the Upper Triassic [12].

In the valley of the river was discovered Dapsićke same layout layers. From the middle of limestone composed of the surface slope and Oštro, Tivrana, rim Police, Krčevsko Peštarska plateau of Bjelasica (at Ursulovačkog lakes, rivers Jelovice right side) and a lonely hill in the valley. Flaky limestone can be found in the area of Plav and Gusinja and to disappear in places where the layers of this formation to the south and southwest. In the Bistrica gorge Buča calcareous layers have vertical position. Tabular limestone bed of are subject in Lima. On are bottom of that basin drilling led to the limestone at a depth of 70-320 $\mathrm{m}$ [18]. Dibasic-chart formation occurs between Tivrana and Berane original work Dapsićke and Kaludarska River (town Budimlja) in the form of sandstones, charts, shale's, marls and marl limestone's.

From the standpoint of Agriculture for the Middle Triassic relate soil types (Kalkomelanosol, Kalkokambisol, rankers) that have greater significance for agriculture and whose land productivity is low (beech, fir, spruce). If on the other hand, matrix substrate attached to rigosol, then the land can be used for agricultural production (orchards, grasslands) [19].

Upper Triassic dolomite limestone is belonging to the gray, light gray or whitish color (Prokletije Mountain and ridges above Gusinja). In the Valley of Biograd River the river Martinovića, Kutska and range of Komovi discovered district limestone. 
Micro association are corresponds Middle and Upper Triassic limestone's and these are so specific. For the Upper Triassic as the parent material related land (Kalkomelanosol, Calkocambisol), whose agricultural productivity is low. The Holocene is prevalent along the river Lim to Plavsko the lake, river riverbed Ljuče, Vrulje and Grnčara, while the most prominent Devojački Pleistocene karts. Parent material for the soil bound (rendzina, rigosol, luvisol), relatively suitable for agricultural production (land of intense fruit and forest trees).

In Berane basin developed Miocene (Bukovac, part Glavica Jasikovac, Petnjik, Budimlja, Prosjana foot) freshwater strata. These layers show a variety of facial, cement marl look, sand, clay and sand. Marls are the most compact, represented mainly in Budimlja village, on the right side of Lima, mostly on the police, Jasikovac, but also in the hamlet Đurake. These marls by their qualities match the requirements of the cement industry in and of reserves, Jasikovac could be provide for the production of two hundred years ago, if you would annually produce 80.000 tons [20]. From the point of view of agriculture for the parent material related soil (podzol, rendzina, distric cambisol) that may be suitable for agricultural production, they have linked to loam-clay layer. Tertiary strata have commonly fractured and often exceed a thickness of 150-250 m. The Tertiary strata are Berane lowland freshwater mollusk remains of many [12].

Jurassic formations have detected in Bašća, Kruščice Bogaja, Murovca and Dapsića, in the form of volcanic-sedimentary formations involved in the building of which sedimentary, igneous and metamorphic rocks. Upper Jurassic formations have found in the general vicinity Gusinja. These are primarily gray limestone containing corals and snails. Of these built of limestone valleys and rivers Ropojanske and Vojuše and mountain ridges in the foothills of the border to Albania [12] Represent the parent material (Lithosol) with sparse vegetation (minimum fertility). Quaternary layers developed as a narrow strip along the river course (Lima, Komarače, Biogradska, Velička River et al.). Alluvial plains are sandy-gravelly sediments and sandy-clay sediments. Layer thickness ranges between 30-50 m. Terraced sediments spread over the alluvial plains of major rivers. They are made of gravel and sandy soil with lots of clay impurities. Talus deposits found on the slopes of the steep limestone slopes compartment Vlahova, Komova and Bjelasica.

Neogene sediments in Jesikovaca, Dubića and Dapsićkog hills reach the height of 750 $800 \mathrm{~m}$ and a depth of $270 \mathrm{~m}$. These sediments consist of clay and marl, are quite compact. Show significant disorder between the harem and Budimlje. On the left side of Lima under fluvial-glacial sediments are sediments at depths $309 \mathrm{~m}$ (Pešca), $313 \mathrm{~m}$ (Dinje), $260 \mathrm{~m}$ (Babinu), $179 \mathrm{~m}$ (Mašte) and $70 \mathrm{~m}$ (Berane basin rim). On the Police can be observed sandy marls and marl limestone's [21].

From the point of view of agriculture Neocene sediments are of great importance. They are highly productive soils parent substrate such as vertisoli (calcareous), eutric cambisol (eutric cambisol), rigosoli, luvisol ... For the terraced alluvial formations such substrates home related soil types of the highest class (fluvisols, eutric cambisols, luvisol et al.). In addition to high quality creations are related to the plane or slightly inclined surface relief. Land the diluvia formations occur as colluviums with certain cultural practices and antierosion measures are potentially fertile land on which to organize agricultural production (vegetables, tobacco).

At the observed area there are also unrelated sedimentary rocks: debris, gravel, sand. Debris is built of fragmented material accumulates not classed - term at the foot of the steep slopes of the north-eastern part of Montenegro or the bottom of the short flows torrent Lima and its tributaries. Application to Debris is very limited - mainly used as a cornerstone for the levees. "Sand is made up of large, rounded and often heterogeneous fragments. Clean gravel 
is a basic concrete filler and a natural ma $\neg$ trials to quickly stabilize, and is used as a bearing curtain in road construction and building construction" [16]. Numerous deposits of gravel and sand are found in the bed of the river Lima (Plav, Andrijevica and Berane). Only in Bandović Bridge, the amount of sand and gravel, are available for an annual exploitation are estimated at about 100 to $120,000 \mathrm{~m}^{3}$. Sand has the same petro graphic, genetic and technical performance but at a much more diverse $\neg$ mean, is used for the manufacture of glass, in foundry, as a building material (making mortar) and others. However, the observed area, except as a construction material, sand unfortunately did not find wider application.

From classic rocks associated with the most significant breccias constructed mainly of angular fragments of rocks, usually of uniform composition, related carbonate, quartz, clay and the like Binder. The compressive strength of the breccias depends on the type of binder. Breccias are nicely polished and are an important dimension stone [16].

Žoljevica on the hill, near Andrijevica is bearing architectural - building stone. The deposit builds medium - Triassic massive gray and white limestone mesmerist. Mesmerist white limestone on the surface, covering an area of $3000 \mathrm{~m}^{2}$ and its thickness is about $30 \mathrm{~m}$, while the gray limestone mesmerist covers an area of $30.000 \mathrm{~m}^{2}$ and has a thickness of about $50 \mathrm{~m}$. The calculated reserves gray marble $\mathrm{B}+\mathrm{C} 1$ category, amount to 2.223 million $\mathrm{m}^{3}$.

Reserves and gray-white white marble belong to $\mathrm{C} 1$ category and amount to about $60.000 \mathrm{~m}^{3}$. Due to their physical - mechanical properties of rock "Žoljevice", can be used to produce plates for covering horizontal and vertical surfaces, buildings in construction (http://www.andrijevica.me) [22]. However, though research marble is not enough attention even though it considered the site, after Prilep and Arandjelovac, could be consider as one of the most significant in the former Yugoslavia. Wonderful marble with "Žoljevice" we should "valorize" the artistic and tourist event, "marble and sounds".

Ground stability built of unconsolidated sedimentary rocks (gravel and sand) depends on their size distribution and density of the rock mass. Water does not significantly change their physical and chemical properties. Gravels are loose and poorly compressible and are suitable for foundation structures. Execution of underground works, however, in them is practically impossible. Sands are loose, and when they have saturated with water is poorly mobile. When constructing the foundations in sands of great importance to the presence of clayey components that reduces their capacity.

The underground works are avoiding them. Stability of buildings on the grounds of the clay depends on their level of cohesion, the clay; there are two phases of settlement: the first immediately after exercise, which has manifested in the form of rapid lateral displacement, and other light and long-term subsidence that may last for decades. Because of the properties of some clays swell, have thyrotrophic properties that are compressible, above all, a company built on them, must been made in detail - analyzes of these rocks. Underground works in them are running slow due to frequent swelling and facilities must be immediately transparent strong support. Are channels, basins and hydraulic reservoir facilities, for waterproofing clay as possible? Slope stability and cuttings in small clay (http://www.pmf.ni.ac.rs) [14].

\section{CONCLUSION}

In the northeastern part of Montenegro, municipalities Berane, Andrijevica and Plav can clearly be distinguished following spatial areas with different geological, and thus a different significance for the economy, namely: 
1. Courts metamorphic and igneous rocks, which in varying degrees characterized Pathogenic impoverishment,

2. Courts sedimentary rocks which are developed soil of considerable production values, as follows:

a) Alluvial and terrace cropping sediments that have formed the most favorable soil physical and chemical properties and production,

b) Sediments from land with high production potential, but slightly lower than in the soil with alluvial and terrace cropping sediments.

With point of construction, we have:

1. Spaces metamorphic rocks have characterized by difficulty in performing surface and underground works in flinch, which also applies to the fields constructed from serpentines

2. Courts made of fresh intrusive rocks have very favorable characteristics for the construction of virtually all facilities. However, if the rock mass tectonically broken or decayed, its quality as a medium similar to the unrelated sedimentary rocks and

3. Ground stability built of unconsolidated sedimentary rocks (gravel and sand) depends on their size distribution and density of the rock mass. While the stability of buildings on clay courts depends on their level of cohesion.

Geological research has be performed in this part of northeastern Montenegro, in the course of geological mapping has registered some new phenomena of mineral resources. Specifically, the minerals in the studied area can be dived into the following groups:

1. Ore occurrences related to the sediments of the upper Oligocene and lower Miocene,

2. Metals appear related to Paleozoic and Lower Triassic sediments and

3. Volcanogenic-sedimentary rocks of the Middle Triassic formation no metal and minerals related to Triassic sediments, Cretaceous, Neocene and Quaternary.

Thanks to the geologic structure of the basin Beranske, there are significant reserves of brown coal and lignite, which provide excellent conditions for the development of mining. Coal Beransko - Poličkog basin is widespread in all parts of the valley (Budimlja, Petnjik, Zagorje, Polica, Beran Selo and Dolac). Total coal reserves amount to 176.231.197 tons. Development Program me Beranske coal production in the basin, would cause the intense regrouping and integration of industrial enterprises, which could cause the need to expand capacity (Beran Selo, Dolac) [23].

GeoScape in considered are detected and the occurrence and prospecting following metals: lead, zinc, copper, iron and pyrite [24]. Since no mineral resources, there are deposits of gravel deposits, sand, building materials and ornamental stone. It would take emphasis, what mineral wealth and what are all the potential for metals, non-metals and especially (marble and marble breccias), to provide this part of eastern Montenegro, for its economic development. Research that is lower or higher intensity exercise, leading to the discovery of new ore deposits, so we are not inclined to such estimates. However, we believe that the mining industry and the observed area, due to the presence of mineral resources, that is, their versatility and reserves, with only partial advantage of the opportunities it gives the raw material base.

Numerous development and environmental issues need to be imposed as soon as possible approaches to concrete actions for the sustainable management of mineral resources. In the field of environmental protection is necessary to implement the Strategy for the 
sustainable development of mineral resources with special emphasis on its environmental component.

Sustainable Development Strategy whose acronym reads a SARM (aggregates Sustainable resource management - Sustainable management of mineral resources) deals with themes of safe, sustainable and uninterrupted supply of mineral resources. Ensuring reliable and uninterrupted access to mineral resources is becoming increasingly important factor in European competition and the release of European Commission.

The raw materials Initiative - Meeting our critical needs for growth and jobs ("Management of raw materials - meeting our needs for growth and creating jobs") defined three policies in this area: unrestricted access to mineral resources, the sustainable supply of mineral resources and increase efficiency and promote recycling (www.sarmaproject.eu) [25]. SARM project at the local level based on the following activities: to optimize the efficiency of production of primary raw materials, prevent or minimize the environmental impact of operation, minimize the number of illegal quarries, promote recycling (waste from construction and demolition) and increase the capacity stakeholders. At the regional level, SARM has based on the assessment of quantity of mineral raw materials and transport links, developing strategies for sustainable management of mineral resources, as well as protected areas. Also are taking into account the balance of minerals in the definition of land use planning and land management, course guidelines developed and procedures for planning the sustainable supply of mineral resources (www.sarmaproject.eu) [25].

Threats to the environment and its reproductive capacity are only one, but not the only example that points to the dangerous pitfalls meanderings and short of previous technoeconomic development. Therefore, a new approach to development must been based on the perception of science and technology dominant in the new environmental Instead of the techno-economic paradigm. Therefore, the conclusion that requires immediate access to defining regional development strategy in building the competitiveness of the economy [26].

By Cvijanović [27]: "The prevailing view that the organization of an important resource, as important as raw materials, energy, equipment, technology and personnel, and perhaps more important because it brings together all the resources and makes them meaningful .... In practical dealing with organizational issues, still dominate the descriptive and analytical approach, and lacks an active attitude towards the perceived organizational changes. The effectiveness and efficiency of the approach to solving organizational problems is impaired ... for different individual ideas and approaches". Of course, we advocate for those programs that meet high scientific criteria, and willingness to appropriate institutions in economic development of specific territory invests the necessary funds.

\section{References}

[1] Malkoč I., The economic significance of geological structure of Europe, 1975, pp. 1. Available from: http://www.geografija.hr,

[2] Rajović G., Bulatović J., International Letters of Social and Humanistic Sciences 3 (2013) 10-30.

[3] Rajović G., Journal of Road and Traffic Engineering 57 (1) (2011) 44-52.

[4] Rajović G., Journal of Studies in Social Sciences 4 (1) (2013) 24-51. 
[5] Knežević M., Regions Plav-Gusinje - conditions for tourism development, Serbian Geographical Society, Belgrade, 1979.

[6] Kasalica S., Northern Montenegro, "University comes", Nikšić, 1988.

[7] Kićović M. D., Tourism and nature protection Upper Polimlja, "University comes", Nikšić, 1995.

[8] Nikolić S., Nature and Tourism of Montenegro, Institute for the Protection of Nature, Podgorica, 2000.

[9] Rajović G., Journal Industry 38 (4) (2010) 183-202.

[10] Fund technical documents geo Federal Bureau, Explain the basic geological map of the Socialist Federal Republic of Yugoslavia - list Ivangrad, Federal Bureau Geo, (1970), pp.16-63.

[11] Group of Author, Review of mineral resources, Federal Geo Institute, Belgrade, 1982.

[12] Bešić Z., Geology Montenegro, Montenegrin Academy of Sciences and Arts, Titograd, 1980, pp. 39-359.

[13] Rajović G., Geographical basis for the development of the economy of the Upper Polimlja, Printing "Vedes", Belgrade, (2005), pp. 20-21.

[14] The technical properties of rocks, (24.12 2010), Available from: http://www.pmf.ni.ac.rs

[15] About Berane (articles, reports, serials), (25.12 2010), Available from: http://www.beranetownnet

[16] Putnik S., Methodology copper Jurassic dibasic - chart formation and its comparison with the Triassic spilite - keratophyre - porphyrite formation in Podrinje - Polimlje area (PhD Thesis), Faculty of Mining and Geology, Belgrade (1979).

[17] Some physical and mechanical properties and its use in construction of major igneous, sedimentary and metamorphic rocks, (22.12 2010),

Available from: http://www.rgf.ac.rs

[18] Bešić Z., Geological Guide to the People's Republic of Montenegro, Geological Society of Montenegro, Titograd, 1959, pp. 12-20.

[19] Rajović G., Journal Industry 37(4) (2009) 15-27.

[20] Boričić R., Lutovac M. V, Petrić D., Commune Ivangrad, Workers' University Ivangrad, Ivabgrad, 1967, pp. 35.

[21] Lutovac V. M., Valley Ivangrad (Berane), Serbian Academy of Sciences and Arts, Belgrade, 1957, pp. 52.

[22] Municipality Andrijevica, The content of spatial and urban planning, (21.12 2011), (2010), Available from: http://www.andrijevica.me

[23] Nikolić P., Dimitrijević D., Coal Yugoslavia, "Innovation", Belgrade, 1990, pp. 359-364.

[24] Rajović G., Bulatović J., Journal of Sustainable Development Studies 2(2) (2013) 229-241. 
[25] SARMa project, Available from: http://www.sarmaproject.eu (29.04 2013).

[26] Vojnović B., Riznić D., Borić S., Journal Industry 37( 4) (2009) 29-61.

[27] Cvijanović J., Organizational Changes, Institute of Economics, Belgrade, 2004, pp. 21. 